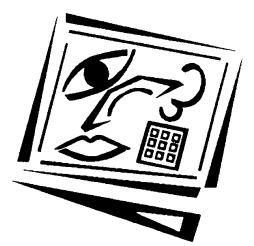

\title{
Towards meaningful learning through digital video supported, case based teaching
}

\author{
Päivi Hakkarainen, Tarja Saarelainen and Heli Ruokamo \\ University of Lapland, Finland
}

\begin{abstract}
This paper reports an action research case study in which a traditional lecture based, face to face Network Management course at the University of Lapland's Faculty of Social Sciences was developed into two different course versions resorting to case based teaching: a face to face version and an online version. In the face to face version, the teacher designed and produced three digital video supported case studies with the students to be used as learning material for the online version. The research focuses on finding out the student perspective on the following questions:(1) Can designing and producing digital video supported cases constitute a meaningful learning process for the students? (2) Can solving digital video supported cases in an online course support meaningful learning for the students? and (3) What roles do the digital videos play in the online students' meaningful learning process? The research indicates that both designing and producing, as well as solving the digital video supported cases, promoted especially the active and contextual aspects of the students' meaningful learning as well as the students' positive emotional involvement in the learning process. Several implications for further development of the Network Management course and for the development of university teaching across disciplines can be drawn from the results.
\end{abstract}

\section{Introduction}

This paper reports an action research case study in which a traditional lecture based, face to face Network Management course at the University of Lapland's Faculty of Social Sciences was developed into two different course versions resorting to case based teaching (Enkenberg, 2001; McLellan, 2004): a face to face version and an online version. In the face to face version the teacher designed and produced three digital video supported case studies with the students for the online version to be used as learning material (see Hakkarainen \& Saarelainen, 2005a). The aim of the research was to develop the teaching and learning processes realised and learning outcomes achieved on the Network Management course, which focuses on the area of public administration and management. 
The general aim of this action research has arisen from challenges faced by higher education, resulting from changes in working life and advances in digital video (DV) technology (Jonassen, Howland, Moore \& Marra, 2003; Kearney \& Schuck, 2004, 2005). Working life requires increasingly specialised expertise and constantly changing responsibilities, and circumstances in the workplace necessitate flexibility, mobility and constant improvement of one's abilities. These challenges have been argued to relate to the problem solving skills of both experts working outside universities and researchers and teachers at universities. Case based teaching has been identified as an approach that has potential to meet these challenges (Enkenberg, 2001).

Regarding teaching of public administration, one of the most important reasons for transforming traditional lecture based courses into online courses is new forms of state organisation which integrate the interactions and interrelations between the state and the citizens, private businesses, customers, and public institutions, through the deployment of modern information and communication technologies (ICTs) (Schedler, Summermatter \& Schmidt, 2004). Therefore, staff in public administration will need skills to operate in different kinds of electronic environments.

The term government is replaced by the term governance that refers to shifts in the operational environment. The government as a vertical, top down relationship is replaced more and more often by horizontal relationships. As a consequence of this transformation, the former public hierarchies have become replaced by networks, dominated by the insecurity of interdependencies (Snellen, 2005). Therefore, the operational environments of employees in public administration set up new qualifications that should be practised already in education. Online courses follow the transformation of the real working life from the viewpoint of both substance and practice.

Despite technological advancements, the pedagogical possibilities afforded by DV are presently still largely unrealised in teaching at the university level, with some exceptions such as medicine (e.g. Wiecha, Gramling, Joachim \& Vanderschmidt, 2003), teacher education (Brophy, 2004), and foreign languages teaching (e.g. Forger, Lyddon \& Penfield, 2005). In depth research into the educational use and especially production of DV in higher education is scarce (Jonassen et al., 2003; Kearney \& Schuck, 2004, 2005). The existing research has nevertheless suggested that the use of DVs can stimulate students' emotions and enhance the authenticity of learning (Bliss \& Reynolds, 2004) and that the production of DVs can enhance university students' motivation, supporting especially the creative and active aspects of learning (Hung, Keppell \& Jong, 2004). 


\section{Theoretical backround}

\section{Teaching and meaningful learning}

In this research teaching and learning are seen as logically distinct processes that are in a reciprocal relationship with each other (Ausubel, Novak \& Hanesian, 1978). Anderson, Rourke, Garrison and Archer (2001) have proposed the concept of teaching presence, which includes: (1) design and organisation, (2) facilitating discourse, and (3) direct instruction. However, teaching performed by the teacher does not necessarily lead to students' learning (Engeström, 1982). The concept of learning refers in this research to (1) students' learning processes, and (2) students' learning outcomes. Learning outcomes are a very complex issue, especially since learning is by nature unconscious; students cannot necessarily learn by simply deciding to learn something (Ausubel et al., 1978; Kansanen et al., 2000; Yrjönsuuri \& Yrjönsuuri, 2005). This research draws upon the model for teaching and meaningful learning (TML), which is presented in Figure 1. The model has been developed on the basis of the integrated model of network based education (NBE) introduced by Vahtivuori et al. (2003). In the model, the concept of network refers to both collaborative and technological networks.

\begin{tabular}{|c|c|c|c|}
\hline Teaching & & & ngful Learning \\
\hline $\begin{array}{l}\text { Design and } \\
\text { organisation of } \\
\text { the learning } \\
\text { environment for } \\
\text { students' } \\
\text { meaningful } \\
\text { learning } \\
\text { Support and } \\
\text { guidance for } \\
\text { students' } \\
\text { meaningful } \\
\text { learning }\end{array}$ & $\begin{array}{l}\text { Pedagogical } \\
\text { imodels or } \\
\text { approaches, } \\
\text { e.g. } \\
\text { Case based } \\
\text { teaching } \\
\text { Problem based } \\
\text { learning }\end{array}$ & 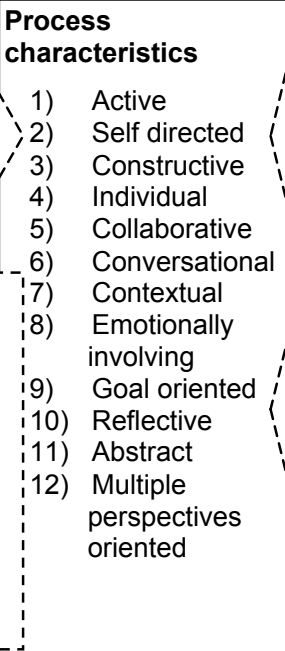 & $\begin{array}{ll}\text { Outcomes } \\
\text { 1) } \\
\text { Domain specific } \\
\text { 2) } \text { Transfedge } \\
\text { skills: } \\
\text { Inforable, generic } \\
\text { Metacognition } \\
\text { Problem recognising, } \\
\text { identifying and solving } \\
\text { Higher order thinking: } \\
\text { critical thinking, creative } \\
\text { thinking, reasoning, } \\
\text { planning, analysing } \\
\text { Abstract thinking } \\
\text { Collaboration and } \\
\text { cooperation } \\
\text { Communication } \\
\text { ICTs } \\
\text { Self-directed learning }\end{array}$ \\
\hline
\end{tabular}

Figure 1: TML model for teaching and meaningful learning. 
Meaningful learning is in this research understood as an upper level concept that can be realised through various pedagogical models or approaches. In this research, a case based teaching approach was applied. It has been argued to offer a valuable instructional strategy for both face to face courses and online courses (McLellan, 2004), across disciplines (Barnes, Christensen \& Hansen, 1994). It has been acknowledged as one of the instructional models, in addition to others, for example problem based learning (PBL), suited for developing of university teaching (Enkenberg, 2001). The strength of the approach has been argued to lie in enhanced learner interest and engagement, and also in improved skills in retention, problem solving and critical thinking (McLellan, 2004). Case based teaching provides a learning environment in which students exercise the skills of problem solving, decision making, collaboration, analysing, criticising, making judgments, and expressing reasoned opinions, while facing realistic problems. McLellan (2004, pp.14-15) defines an ideal case as "an open-ended story that calls for complex, subtle information from multiple points of view".

Meaningful learning is defined through 12 process characteristics and expected outcomes, including students' (1) domain specific knowledge and (2) transferable, generic skills (NCVER, 2003; Tynjälä, 2001). The process characteristics of meaningful learning include the critical factors fostering the development of generic knowledge and skills (CDSL \& CLREP, 2000), that is, skills that apply across a variety of jobs and life contexts. This research acknowledges the crucial meaning of all the three components of the TML model: teaching, meaningful learning process, and learning outcomes. However, the focus of this paper is mainly on the realisation of the process characteristics of meaningful learning.

\section{Characteristics of meaningful learning}

The characteristics of meaningful learning used in this research have been constructed from the characteristics of meaningful learning by Jonassen (1995, 2000, 2002), Jonassen et al. (2003), Ruokamo and Pohjolainen (2000), Ruokamo (2001), and Ruokamo, Tella, Vahtivuori, Tuovinen and Tissari (2002). In addition, Soini's characteristics of good learning situations (1999; Flynn \& Soini, 2000) were selected because of his emphasis on the role of emotions and on the awareness of different perspectives in good learning situations. Worth noting is that the characteristics are very much in accordance with the set of characteristics introduced by Herrington, Oliver and Reeves (2003; see also Herrington \& Oliver, 1995) in their discussion on authentic activities within online learning environments. The selected characteristics of meaningful learning and the characteristics from which they were selected are presented in Table 1 . The characteristics guided the design of the course and the evaluation of the students' experiences. 
According to these characteristics, meaningful learning is (1) active, (2) selfdirected, (3) constructive, (4) individual, (5) collaborative, (6) conversational, (7) contextual, (8) emotionally involving, (9) goal oriented, (10) reflective, (11) abstract, and (12) multiple perspectives oriented.

Table 1: Characteristics of meaningful learning utilised in the research, and the characteristics from which they were constructed.

\begin{tabular}{|c|c|c|c|c|}
\hline $\begin{array}{c}\text { Characteristics } \\
\text { selected }\end{array}$ & $\begin{array}{c}\text { Jonassen } \\
(1995,2000, \\
2002)\end{array}$ & $\begin{array}{c}\text { Jonassen et al. } \\
\text { (2003) }\end{array}$ & $\begin{array}{c}\text { Ruokamo \& } \\
\text { Pohjolainen } \\
(2000) ; \\
\text { Ruokamo } \\
\text { (2001); } \\
\text { Ruokamo et al. } \\
\text { (2002) }\end{array}$ & $\begin{array}{l}\text { Soini (1999); } \\
\text { Flynn \& Soini } \\
\quad(2000)\end{array}$ \\
\hline 1. Active & Active & $\begin{array}{l}\text { Active } \\
\text { (manipulative/ } \\
\text { observant) }\end{array}$ & $\begin{array}{l}\text { Active and } \\
\text { Self directed }\end{array}$ & Autonomy \\
\hline 2. Self directed & - & - & & \\
\hline 3. Constructive & Constructive & $\begin{array}{l}\text { Constructive } \\
\text { (articulative / } \\
\text { reflective) }\end{array}$ & $\begin{array}{l}\text { Constructive } \\
\text { and cumulative }\end{array}$ & - \\
\hline 4. Individual & - & - & Individual & - \\
\hline 5. Collaborative & Collaborative & \multirow{2}{*}{$\begin{array}{l}\text { Cooperative } \\
\text { (Collaborative / } \\
\text { conversational) }\end{array}$} & $\begin{array}{l}\text { Cooperative } \\
\text { and communal }\end{array}$ & Collaboration \\
\hline $\begin{array}{l}\text { 6. Conversat- } \\
\text { ional }\end{array}$ & Conversational & & $\begin{array}{l}\text { Conversational } \\
\text { and interactive }\end{array}$ & Dialogue \\
\hline 7. Contextual & Contextualised & $\begin{array}{l}\text { Authentic } \\
\text { (complex/ } \\
\text { contextualised) }\end{array}$ & $\begin{array}{l}\text { Contextual and } \\
\text { situational }\end{array}$ & - \\
\hline $\begin{array}{l}\text { 8. Emotionally } \\
\text { involving }\end{array}$ & - & - & - & $\begin{array}{l}\text { Emotional } \\
\text { involvement }\end{array}$ \\
\hline 9. Goal oriented & Intentional & \multirow{2}{*}{$\begin{array}{l}\text { Intentional } \\
\text { (reflective/ } \\
\text { regulatory) }\end{array}$} & $\begin{array}{l}\text { Goal oriented } \\
\text { and purposive }\end{array}$ & - \\
\hline 10. Reflective & Reflective & & Reflective & $\begin{array}{l}\text { Reflection and } \\
\text { feedback }\end{array}$ \\
\hline 11. Abstract & - & - & Abstract & - \\
\hline $\begin{array}{l}\text { 12. Multiple } \\
\text { perspectives } \\
\text { oriented }\end{array}$ & - & - & - & $\begin{array}{l}\text { Possibility to } \\
\text { see things from } \\
\text { new or different } \\
\text { perspectives }\end{array}$ \\
\hline
\end{tabular}

The characteristics provide a fairly wide and general enough perspective from which to assess learning processes within different subject areas (see also Karppinen, 2005). Meaningful learning processes should, nevertheless, not be understood as processes in which all of these characteristics are met all the time. In addition, the characteristics are intertwined, interdependent, interactive, partly overlapping, and synergetic (Jonassen et al., 2003), and should therefore be seen as flexible by nature (Ruokamo et 
al., 2002). In the following paragraphs a concise description of the process characteristics of meaningful learning is presented and the role of DVs is discussed.

For Jonassen, (1) active learning means that "learners are engaged by the learning process in a mindful processing of information, where they are responsible for the result" (1995, p.60). Students are encouraged to ask questions, acquire information, critically evaluate information, express new ideas and models of thinking (Ruokamo et al., 2002), and use different productivity tools and cognitive tools (e.g. videos) in their learning environments (Jonassen, 1995, 2000). (2) Self direction in learning refers to "a process in which a learner assumes primary responsibility for planning, implementing, and evaluating the learning process" (Brockett \& Hiemstra, 1991, p.24). The concept is thus intertwined with the characteristics of activeness, goal orientedness, and reflection. (3) Constructive learning means that learners accommodate new ideas into their prior knowledge in a process of meaning making, not of knowledge reception (Jonassen, 1995, 2002). For Ruokamo et al. (2002), (4) individuality means that learners have individual learning styles and strategies and that learning and studying are always influenced by students' prior knowledge, conceptions and interests.

Working (5) collaboratively makes it possible that students can exploit each other's skills and provide social support and modeling for other students. Collaborative and (6) conversational learning is a dialogue, that is, a process of internal and social negotiation. (Jonassen, 1995, 2002.) At its best, collaborative work also provides students with opportunities for a positive sense of social inclusion, which can be seen as an important component of motivation to learn (Wosnitza \& Nenniger, 2001). (7) Contextual learning resorts to learning tasks that are either situated in meaningful, real world tasks or simulated through a case based or problem based learning environment (Jonassen, 1995, 2000).

(8) Emotion is intertwined with cognition, motivation and learning by affecting perceptions, theoretical imagination, and logical reasoning (Puolimatka, 2004; Schutz \& DeCuir, 2002). According to Soini (1999, p.84), emotional involvement is the most important feature of good learning situations for the students and it emerges from "feelings of personal, emotional connectedness to some subject." Positively toned emotions experienced during the learning process such as interest, joy, surprise (Puolimatka, 2004), and emotions resulting from mastery experiences (Bandura, 1994; Engeström, 1982) have been shown to be vital for learning. However, a successful learning process may also include occasional negatively toned emotions (Kort \& Reilly, 2002; Liimatta \& Karppinen, 2003; Op't Eynde, De Corte, \& Verschaffel, 2001). 
In a (9) goal oriented learning process, students work actively to achieve a cognitive goal, and can define learning objectives of their own (Jonassen, 1995; Ruokamo \& Pohjolainen, 2000). Intertwined with goal orientation is the process of (10) reflection (Jonassen, 1995, 2000). In a reflective learning process, students express what they have learnt and examine the thinking processes required during the process (Jonassen, 1995; Ruokamo \& Pohjolainen, 2000). (11) Abstract learning can be defined as the construction of new ideas at an abstract level. The development of theoretical ideas reaches from practical experience to a deeper level (Lehtinen, 1997; Ruokamo et al., 2002). Soini (1999) argues that learning situations that (12) lead to an awareness of different perspectives are experienced by students as good and real learning situations.

DVs should accordingly function as tools for meaningful learning by representing and simulating meaningful, real world situations, problems or contexts; by representing the beliefs, perspectives and stories of others; and by supporting discourse among pupils. (Jonassen, 1995, 2000; see also CTGV, 1993; Ruokamo, 2001; Ruokamo et al., 2002). In order to support meaningful learning, students should be critical users and producers, rather than consumers, of DVs. Producing videos requires students to engage in more active, constructive, intentional, authentic and cooperative roles and in critical and creative thinking. (Jonassen et al., 2003.)

\section{Research objectives and questions}

The objectives of this action research case study were to develop the teaching and learning processes realised and learning outcomes achieved on the Network Management course, in order to better support meaningful learning. The research focuses on finding out the student perspective on the following questions:

1. Can the face to face, case based teaching approach applied on the course, that is, designing and producing digital video supported cases, support a meaningful learning process for the students (see Jonassen et al., 2003)?

2. Can the digital video supported, online, case based teaching approach applied on the course, that is, solving digital video supported cases, support meaningful learning for the students from both the process and outcome point of view (see CTGV, 1993; Enkenberg, 2001; Jonassen, 1995, 2000; McLellan, 2004; Ruokamo, 2001; Ruokamo et al., 2002)?

3. What roles do the digital videos play in the students' meaningful learning process from the perspective of the digital video supported, online, case based teaching approach applied on the course (see Jonassen et al. 2003)? 


\section{Research methods}

The research was conducted in 2004-05 as an action research case study in which the teacher worked alongside the researcher with the assistance of an extensive network of actors (see Hakkarainen \& Saarelainen, 2005a). The research functioned as "a small scale intervention in the functioning of the real world and a close examination of the effects of such an intervention" (Cohen \& Manion, 1994, p.186). The research process followed Lewin's (1948) definition of the main stages of an action research process: planning, acting, observing and reflecting. The planning stage took place in AprilAugust 2004. Both versions of the Network Management course were realised, and the research data was collected during September 2004-April 2005. During the academic year 2004-05 the course was arranged in two different versions: the face to face version and the online version. All the course activities and the research questionnaire were conducted in Finnish.

\section{The face-to-face version of the Network Management course}

The face to face version was implemented in autumn 2004 with eight students. These students produced the DV supported cases for the online version of the course that was implemented during spring 2005. The three DVs produced were simulations of possible social situations related to the open ended, real life cases. Their function was to illustrate the cases and to act as the starting point and context for learning. The duration of the videos varied from 13 to 20 minutes and they were distributed to the online students in CD format. The real life cases were selected after reading theoretical articles on the topics of the course. The students received 2 ECTS (European Credit Transfer System) credits for designing and producing one filmed case. The first case dealt with a current, sometimes heated debate on how to develop the local Ounasvaara ski and recreational area. The students interviewed experts from local organisations representing the debate in real life. The video portrayed a meeting in which the local experts debated the issue. Each student acted out the role of the local expert who she/ he had interviewed (Figure 1).

The second case, the Finnish Sports Federation, was chosen as the organisation whose networking competence was to be measured, and the video portrayed a meeting related to the issue. Again, the students and the teacher were acting on the video. The third case was chosen by the teacher and it was based on research into the innovation networks and network management strategies applied in these cases. The interviews for the research were done by the teacher (see Aho, Saarelainen, \& Suopajärvi, 2004). The video portrayed the students and the teacher discussing a local municipality innovation project. The students were responsible for the 
scriptwriting and acting on the videos, while the actual shooting and editing was done by a professional video production unit.

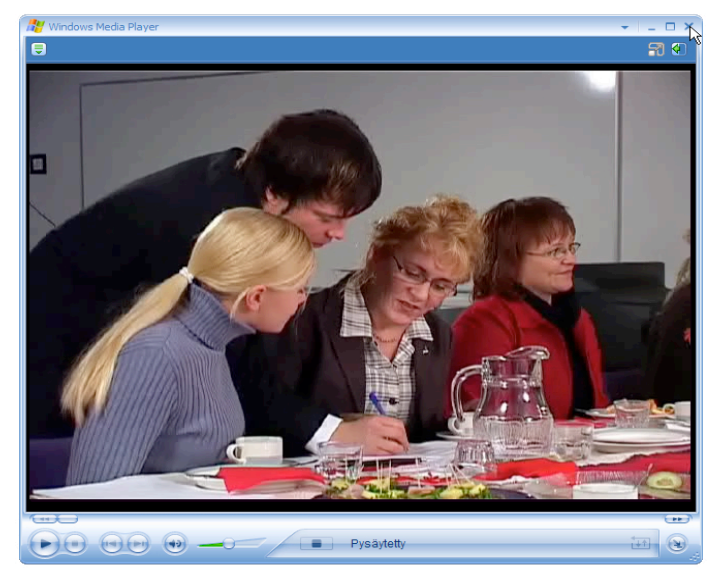

Figure 1: A screenshot of the first digital video.

\section{The online version of Network Management course}

The students $(n=33)$ enrolled in the online version used the three DV supported cases as their learning material. Other learning material included scientific articles, a book, web pages related to the real life cases, and the PowerPoint slides for the introductory lecture. The students came from different parts of Finland and their age varied between 22 and 51 years. $77 \%$ of the respondents were female. The timeline of the course was two months. The course started with a four hour introductory, face to face lecture, after which the students engaged in case based online studying in groups of 3 to 5 students. The Finnish Discendum Optima learning management system (Figure 2) resembling others such as WebCT and Blackboard was used for providing guidance for the students, for small group conversations, for delivering the course materials, and for preparing the learning tasks. The pedagogical rationale for the online course was to support students' skills in operating in electronic environments, which are increasingly becoming the operational environments of employees in public administration.

As their collaborative learning task, the small groups wrote future scenarios (Case 1), planned the measurements for the self evaluation of networking activity (Case 2), and devised a networking strategy for a local innovation network (Case 3). The students' learning outcomes were assessed with grades 1-3. The assessment was based on the learning tasks and on the students' learning diaries. 


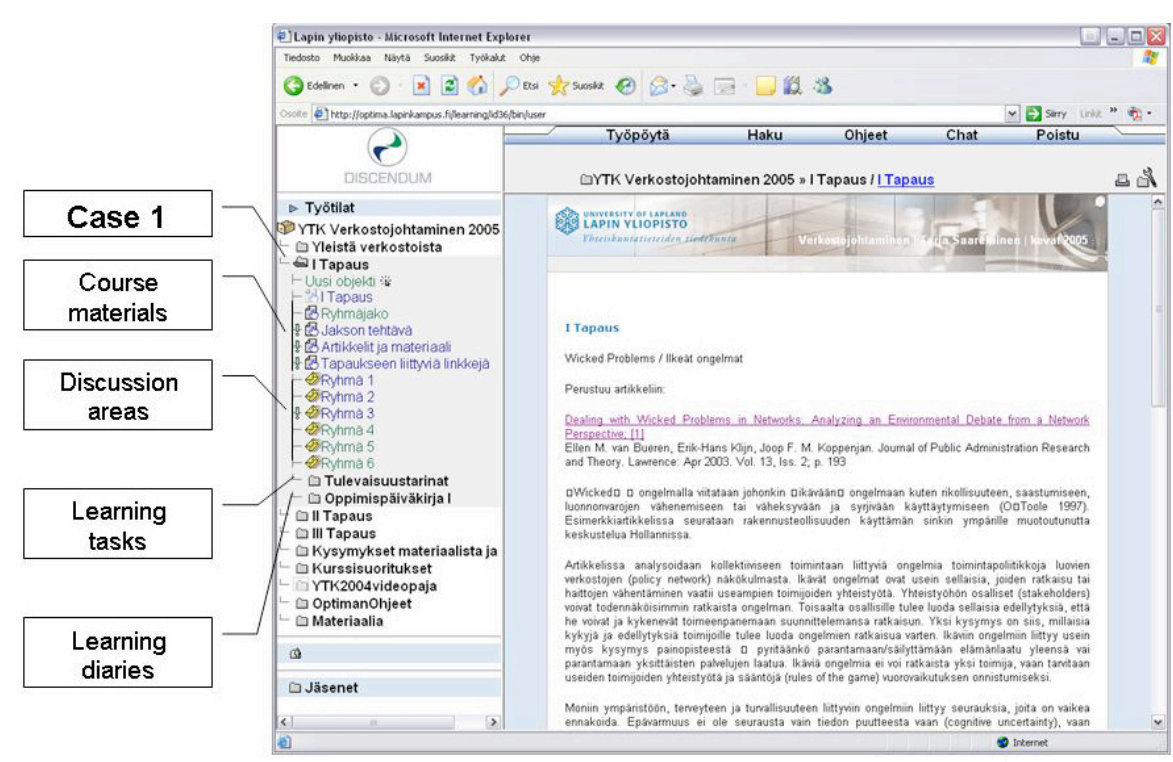

Figure 2: A screenshot of the Discendum Optima learning management system.

\section{Data gathering and analysis}

The first research question was: "Can the face to face, case based teaching approach applied in the course, that is, designing and producing DV supported cases, support a meaningful learning process for the students?" To answer the question, the DV production diaries of the 8 students enrolled in the face to face version of the course were utilised. The students were instructed to write a diary on their thoughts and emotions concerning the DV production process. The students were able to access each other's diaries in the Discendum Optima learning environment. The diaries contained 3 to 11 entries. A qualitative content analysis was performed on the diaries with respect to the 20 emotions chosen for this research.

Questionnaires completed by the online students were utilised for answering the second research question: "Can the DV supported, online, case based teaching approach applied in the course, that is, solving DV supported cases, support meaningful learning for the students, both from the process and outcome point of view?" Out of the 33 students enrolled on the course, 30 completed the course and the questionnaire. The questionnaire included 31 statements concerning the meaningfulness of the learning process, and the students were asked to evaluate them using a five-point Likert scale. The statements were operationalised according to 
the characteristics of meaningful learning chosen for this study, utilising in part the already existing operationalisations by Nevgi and Tirri (see Nevgi \& Löfström, 2005). 21 Likert scale questions on the questionnaire focused on the students' emotions. The students were asked to indicate to what extent they had experienced a given emotion during the course and to specify the reasons for this emotion. 12 of the 20 emotions listed in the questionnaire were chosen from the emotions suggested by Kort and Reilly (2002) as possibly relevant to learning: worry, comfort, boredom, interest, frustration, uncertainty, dispiritedness, disappointment, satisfaction, enthusiasm, tension, and embarrassment. These emotions were considered lacking in social emotions possibly relevant to collaborative learning: trust, sense of community and irritation. Therefore, these emotions were added on the questionnaire, as well as joy, stress, relief, feelings of inadequacy, and challenge.

The questionnaire data was analysed qualitatively and quantitatively using the SPSS statistical analysis software. The mean values, standard deviations, and percentages of the students' ratings of the practical realisation of the characteristics of a meaningful learning process were extracted (Table 2). The emotions were analysed by extracting the mean values and the standard deviations of the students' ratings (Figures 4 and 5). Being a case study and not seeking statistical significance (Cohen, Manion, \& Morrison, 2003), quantitative analysis was applied as a tool for describing and interpreting the data. The factor analysis of the emotions, documented on the previous research paper (Hakkarainen \& Saarelainen, $2005 b)$ proved erroneous due to typing errors on the original data matrix. A rerun of the analysis with the corrected data proved the Kaiser-MeyerOlkin (KMO) measure for sampling adequacy not high enough (.440).

Questionnaires completed by the online students were utilised for answering the third research question: "What roles do the DVs play in the students' meaningful learning process from the viewpoint of the DV supported, online, case based teaching approach applied on the course?" The questionnaire included both Likert scale statements and open ended questions focusing on the pedagogical role of the DVs. The data was analysed quantitatively by extracting the percentages of the students' ratings, and qualitatively with respect to the themes that were found in the students' answers to the open ended questions.

\section{Research findings}

In the following, the research findings concerning the meaningfulness of learning for the students are presented with respect to (1) the students designing and producing the DV supported cases, face to face, and (2) the 
students solving the DV supported cases online. Thirdly, the research findings concerning the role of the DVs in the meaningful learning process are presented.

\section{The meaningfulness of learning for the students designing and producing the cases}

The students' learning diaries clearly indicate that the face to face, case based teaching approach applied on the course, that is, designing and producing the DV supported cases, contributed to the students' positive emotional involvement in the learning process. The collaborativity, conversationality, activeness, and contextuality of the learning process were most clearly associated with positively toned emotions in the students' diaries. Jonassen et al.'s (2003) arguments about the active, constructive, cooperational, and authentic characteristics of students' video production were thus further confirmed. In addition, the analysis unfolded the positively toned emotions relating to these characteristics.

All in all, the students reported more frequently positively toned than negatively toned emotions. Satisfaction was reported by all of the students. It was mainly related to (1) meetings with the study group, (2) choosing a local case to be simulated, (3) being able to produce learning material for others, and (4) the case based approach as compared to learning through reading books (see also McLellan, 2004). For one respondent the approach had functioned as a bridge between studying and working life:

I also learned to view my studies against the background of my future
working life, for after years of learning from books one may forget the
reason behind the activity. The concrete cases in which we were the actors
increased my motivation so much that now I'm really anxious to enter
working life.

Feelings of interest were reported by seven of the eight students. The reasons included the new way of studying, the general topics of the course, and the fact that local cases were chosen to be simulated. The results point out the benefits of examining local issues for students' emotional involvement. Jonassen et al. (2003) have even argued that by producing video documentaries about local issues, students become more concerned members of society. Choosing the local Ounasvaara case for simulation changed the emotional tone from discomfort, caused by a "distant" case, to interest and enthusiasm. Two of the respondents noted:

I just figured that the Dutch zinc case was a bit too remote, and you probably couldn't get as much out of it as you could of a case more closely related to Finns or the people of Lapland. That is why I was happy we could come up with the idea of choosing Ounasvaara as our subject. 
Having thought about it, a more familiar subject also feels more natural to accomplish. It is also much easier to become interested in a subject and thereby motivated to work when the issue has affected you or is otherwise closer to your thoughts.

Designing and producing the cases was also experienced as a reason for negatively-toned emotions. There was uncertainty about what was actually expected of the students and what it meant in practice to produce the DVs. Clearly, the DV-supported case-based teaching approach implies a change in the more traditional ways of teaching and learning, and students may experience difficulties with orienting in this new situation as the following quotes by the respondents indicate:

The whole idea of preparing teaching material on the web seemed a bit confusing at first, so I attended the first meeting feeling a bit uncertain.

I thought: How does one make a manuscript on such an extensive amount of material? How long do we have to shoot to be able to edit a five-minute scene? How do we gain credits from this?

The students noted that they had worried about whether they would succeed in scriptwriting and acting. They had also been nervous about the interviews with the experts in the local organisations and about acting on the video. However, these initial negatively toned emotions turned into feelings of trust, satisfaction, and enthusiasm. The meetings with the study group, guided by the teacher, were considered the turning point in many cases. The teacher's role was thus seen as a decisive and positive one by many students. The crucial meaning of guidance (Engeström, 1982; Nevgi \& Löfström, 2005) is therefore once again confirmed.

\section{The meaningfulness of learning for the students solving the cases}

Table 2 presents the questionnaire data focusing on the practical realisation of the process characteristics of meaningful learning. The data indicate that the DV supported, online, case based teaching approach, that is, solving DV supported cases on an online course, supported a meaningful learning process for the students, especially with respect to the following characteristics: activeness, constructivity, contextuality, abstractness, reflectivity, and multiple perspectives orientedness. $80-97 \%$ of the respondents agreed or moderately agreed with the statements focusing on these characteristics, which is a highly encouraging result. The result points to the pedagogical possibilities of the case based teaching approach applied in this research (Enkenberg, 2001; McLellan, 2004) for promoting students' meaningful learning processes.

However, on a course resorting to collaboration, the individuality and the self directedness of the learning process may partly diminish. The 
Table 2: The students' $(\mathrm{n}=30)$ ratings $(1=$ disagree, $2=$ moderately disagree, $4=$ moderately agree, $5=$ agree) of the practical realisation of the meaningful learning process on the Network Management course.

\begin{tabular}{|c|c|c|c|c|c|}
\hline \multicolumn{2}{|r|}{$\begin{array}{c}\text { Process } \\
\text { characteristic of } \\
\text { meaningful } \\
\text { learning }\end{array}$} & $\begin{array}{l}\text { Mean } \\
\text { value }\end{array}$ & $\begin{array}{l}\text { Std } \\
\text { dev }\end{array}$ & $\begin{array}{c}\text { Moderat- } \\
\text { ely agree } \\
\text { / Agree } \\
\%\end{array}$ & $\begin{array}{l}\text { Statement on the questionnaire } \\
\text { focusing on the process } \\
\text { characteristics }\end{array}$ \\
\hline 1. & Active & 4.40 & 0.72 & 86.6 & $\begin{array}{l}\text { Students' role is to actively acquire, } \\
\text { evaluate, and apply information. }\end{array}$ \\
\hline \multirow[t]{3}{*}{2.} & \multirow[t]{3}{*}{ - Self directed } & 3.47 & 1.17 & 53.3 & $\begin{array}{l}\text { I was able to influence the content of my } \\
\text { learning tasks. }\end{array}$ \\
\hline & & 3.90 & 0.96 & 70.0 & $\begin{array}{l}\text { The case related discussion groups } \\
\text { directed their own studying process. }\end{array}$ \\
\hline & & 4.17 & 0.87 & 86.6 & $\begin{array}{l}\text { I was able to evaluate my own learning } \\
\text { during the course. }\end{array}$ \\
\hline \multirow[t]{2}{*}{3.} & \multirow[t]{2}{*}{ Constructive } & 4.20 & 0.85 & 80.0 & $\begin{array}{l}\text { I was able to utilise my prior knowledge } \\
\text { about the course topics. }\end{array}$ \\
\hline & & 4.33 & 0.66 & 90.0 & $\begin{array}{l}\text { The course deepened my understan- } \\
\text { ding of what I had learned before. }\end{array}$ \\
\hline \multirow[t]{2}{*}{4.} & \multirow[t]{2}{*}{ Individual } & 3.41 & 1.38 & 51.7 & $\begin{array}{l}\text { It was possible for me to study } \\
\text { according to my own personal style. }\end{array}$ \\
\hline & & 3.93 & 1.02 & 66.7 & $\begin{array}{l}\text { I was able to apply my own practical } \\
\text { experiences during the course. }\end{array}$ \\
\hline \multirow[t]{2}{*}{5.} & \multirow[t]{2}{*}{ Collaborative } & 3.63 & 1.19 & 60.0 & $\begin{array}{l}\text { The students were committed to } \\
\text { collaboration. }\end{array}$ \\
\hline & & 3.43 & 1.22 & 56.7 & $\begin{array}{l}\text { Working in small study groups helped } \\
\text { me to learn. }\end{array}$ \\
\hline \multirow[t]{2}{*}{6.} & \multirow[t]{2}{*}{ Conversational } & 2.93 & 1.02 & 26.7 & $\begin{array}{l}\text { Course discussions on chat helped me to } \\
\text { learn. }\end{array}$ \\
\hline & & 3.07 & 1.02 & 30.0 & $\begin{array}{l}\text { Case related, small group discussions on } \\
\text { the discussion area helped me to learn. }\end{array}$ \\
\hline 7. & Contextual & 4.33 & 0.55 & 96.7 & Case based studying helped me to learn. \\
\hline 9. & Goal oriented & 3.93 & 0.83 & 76.6 & $\begin{array}{l}\text { Studying enabled the achievement of } \\
\text { my personal goals. }\end{array}$ \\
\hline 10. & Reflective & 4.17 & 0.87 & 86.6 & $\begin{array}{l}\text { I was able to evaluate my own learning } \\
\text { during the course. }\end{array}$ \\
\hline 11. & Abstract & 4.30 & 0.79 & 86.7 & $\begin{array}{l}\text { On the course practical examples were } \\
\text { studied in a theoretical framework. }\end{array}$ \\
\hline 12. & $\begin{array}{l}\text { Multiple } \\
\text { perspectives } \\
\text { oriented }\end{array}$ & 4.17 & 0.75 & 86.6 & $\begin{array}{l}\text { The course helped me to understand } \\
\text { different perspectives related to the } \\
\text { topics under study. }\end{array}$ \\
\hline
\end{tabular}

percentage of students agreeing with the statement indicating that they were able to study according to their own personal style was relatively small $(52 \%)$. However, the data doesn't allow for inferences about whether the students would have wanted a more individual or self directed learning process. The collaborativity of the process was not seen to support learning in the way the case based studying was. $57 \%$ of the respondents 
agreed or moderately agreed that collaborative studying in small groups helped them to learn. However, it can be argued that collaboration helped the respondents to learn also through the positively toned emotions associated with it.

The students' ratings for the supportive role of the online discussions on chat and on the discussion area clearly stand out from the results. The great majority of the respondents were not convinced about whether they had actually helped them to learn. Interpreted with the students' ratings on the teachers' support and guidance activities, it indicates a need to enhance the guidance. The students were asked to rate nine statements focusing on the teachers' support and guidance activities, which have been shown to be crucial for meaningful learning (see Nevgi \& Löfström, 2005). The statements were rated somewhat less favourably $(\mathrm{M}=3.50-3.80, \mathrm{SD}=0.66$ 1.00) than the other statements on the questionnaire, but still 60 to $73 \%$ of the respondents agreed or moderately agreed with these statements. An exception to this was the statement: "The teacher supported my studying and learning significantly by giving personal feedback about my studying," $(\mathrm{M}=2.37, \mathrm{SD}=1.00)$ with which only $40 \%$ of the respondents agreed or moderately agreed.

Three statements on the questionnaire focused on the transferability of the learning outcomes. $90 \%$ of the respondents agreed or moderately agreed with the following statement: "I can utilise what I learned on the course in other situations" ( $\mathrm{M}=4.43, \mathrm{SD}=0.77)$, and 93\% agreed with the statement "Cases under study supported the acquisition of knowledge and skills needed in working life" $(\mathrm{M}=4.43, \mathrm{SD}=0.63)$. However, the respondents were not as unanimous about whether the studying had enhanced their problem solving skills, with which only $56 \%$ agreed or moderately agreed $(\mathrm{M}=3.57, \mathrm{SD}=1.14)$. This finding does not unequivocally support the argument about the ability of case based teaching approach to improve students' problem solving skills (see McLellan, 2004).

The positive emotional involvement of the students solving the DV supported cases was evident, thus supporting the notion of the case based teaching as an approach able to enhance learner interest and engagement (McLellan, 2004). The mean values of the respondents' ratings of the positively toned emotions (Figure 4) were clearly higher than those of the negatively toned emotions (Figure 5). The students reported that feelings of challenge $(\mathrm{M}=3.37, \mathrm{SD}=0.62)$, interest $(\mathrm{M}=3.27, \mathrm{SD}=0.79)$, and enthusiasm $(\mathrm{M}=3.00, \mathrm{SD}=0.79)$ had the highest intensity and were associated with the topics of the course, the learning materials, the learning tasks, the locally oriented cases under study, and the small group work. This is an encouraging result, given the crucial meaning of these emotions for a successful learning process (Engeström, 1982; Puolimatka, 2004). 
Satisfaction $(\mathrm{M}=2.77, \mathrm{SD}=0.77)$, joy $(\mathrm{M}=2.70, \mathrm{SD}=0.84)$ and relief $(\mathrm{M}=$ $2.60, \mathrm{SD}=1.04)$ were associated with completing the cases successfully. The course was thus able to offer the students "plateaus", that is, periods during which the students are able to solve the assignments resulting in success experiences necessary for maintaining motivation for learning (Engeström, 1982, pp.22-23).

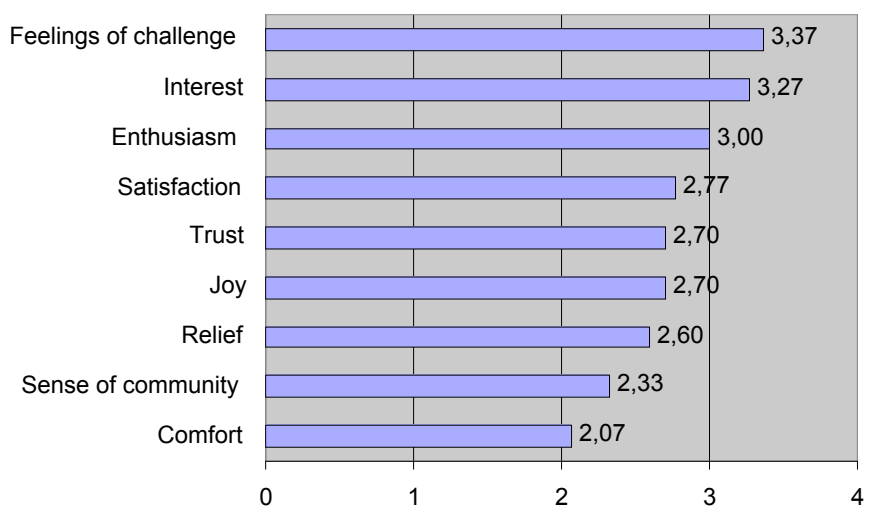

Figure 4: Mean values of the students' $(n=30)$ ratings of the positively toned emotions $(0=$ not at all, $4=$ to a great extent $)$.

Interestingly, even if the respondents were not convinced about whether the online discussions had helped them to learn, several of them mentioned online collaboration as a major reason for experiencing feelings of joy. In this respect, this research further supports the argument that social interaction is a powerful generator of emotions (Averill, 1982). In addition, collaboration generated feelings of trust $(\mathrm{M}=2.70, \mathrm{SD}=0.99)$. According to the respondents, the study group could be trusted in terms of completing the learning tasks.

Of the negatively toned emotions (Figure 5$)$, stress $(\mathrm{M}=2.59, \mathrm{SD}=0.98)$ and uncertainty $(\mathrm{M}=2.23, \mathrm{SD}=1.17)$ were reported as having the highest intensity. The students gave the following reasons for the negatively toned emotions:

1. strict timetable of the course (stress, worry, irritation),

2. abundance of study material (stress, feelings of inadequacy, disappointment),

3. ambiguity of the learning tasks (uncertainty, disappointment),

4. group dynamics (uncertainty, worry, irritation, feelings of inadequacy, frustration, tension), and

5. problems with the learning platform (uncertainty, disappointment, irritation). 


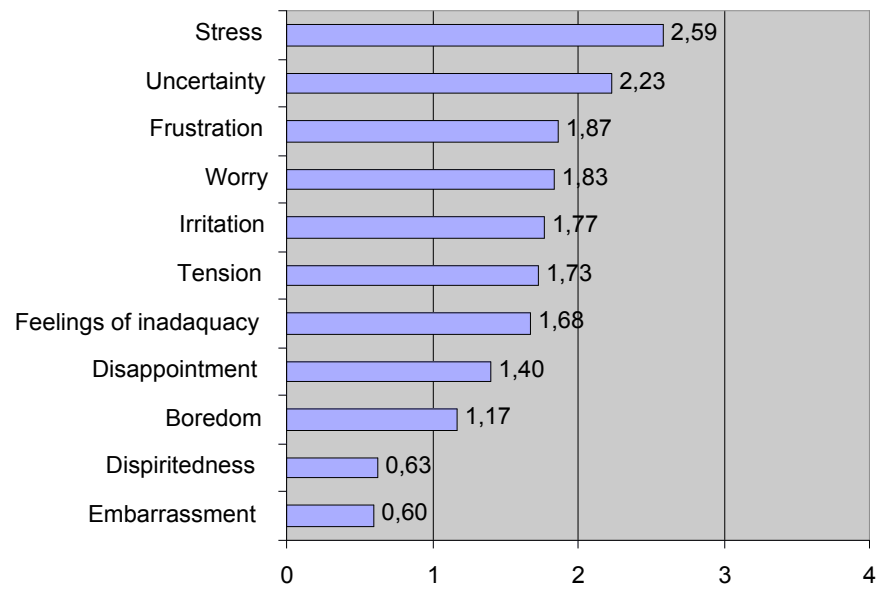

Figure 5: Mean values of the students' $(n=30)$ ratings of the negatively toned emotions ( $0=$ not at all, $4=$ to a great extent).

Collaboration proved a powerful generator of negatively-toned emotions as well (see also Averill, 1982). Several of these, such as frustration ( $\mathrm{M}=$ $1.87, \mathrm{SD}=1.14)$ and tension $(\mathrm{M}=1.73, \mathrm{SD}=1.09)$ were associated with group dynamics: other members' lack of commitment, lack of trust, different working styles, and differences in contribution to the learning task. On the basis of these results it can be stated that successful group dynamics are essential for students' emotional involvement.

\section{The roles of the digital videos in the students' meaningful learning}

The DVs played a supportive role in the DV supported, online, case based teaching approach applied on the course: $60 \%$ of the respondents agreed or moderately agreed that the videos helped them to learn. All of the respondents estimated that the videos illustrated the cases and $81 \%$ evaluated that they had brought added value to the learning process. In the open ended questions, the respondents specified the reasons for the added value. From the viewpoint of a meaningful learning process, it can be concluded that the DVs supported the contextual aspects of learning by "illustrating the cases," as well as by "introducing and clarifying the topics" (see also Wiecha et al., 2003; Jonassen, 1995, 2000). By "illustrating the theories and different perspectives," on the other hand, the DVs also promoted the abstract (Lehtinen, 1997; Ruokamo et al., 2002) and multiple perspectives oriented aspects (Soini, 1999; Flynn \& Soini, 2000) of learning. The DVs enhanced the students' emotional involvement (Soini, 1999; Flynn \& Soini, 2000; see also Bliss \& Reynolds, 2004) by "creating an inspiring 
effect" and "variety" to the studying process. Worth emphasising is also that according to the respondents, one of the roles of the DVs was "to lower the threshold of getting started with studying".

\section{Conclusions}

The research clearly indicates that both designing and producing, as well as solving the DV supported cases, promoted especially the active (see also Hung et al., 2005) and contextual aspects of the students' meaningful learning as well as the students' positive emotional involvement in the learning process. In addition, designing and producing the cases as a face to face process supports especially the collaborative and conversational aspects of meaningful learning. Solving the cases in the online version of the course, on the other hand, was more associated with the abstract, reflective, and multiple perspectives oriented characteristics of meaningful learning. Several implications for further development of the Network Management course can be drawn from the results and we believe that these also have broader implications for the development of university teaching across disciplines.

The locally oriented cases with their learning materials and tasks were associated with intense feelings of interest, challenge and enthusiasm (see also Soini, 1999). Therefore, in the future realisations of the course we want to continue with the locally oriented, case based teaching approach (see also Jonassen et al. 2003). The three separate cases will be preserved, since completing a case successfully was associated with satisfaction, joy and relief (see Engeström, 1982; Bandura, 1994). In future realisations of the course, the reasons for students' negatively toned emotions need to be addressed. For the online students, the improper course timetable was one of the main reasons for negatively toned emotions. However, we are not convinced that simply stretching the timetable will help. Rather, the requirements of online studying, especially the importance of establishing a regular study schedule right from the beginning, need to be discussed at the beginning of the course. Negatively toned emotions resulting from the abundance of study material and the ambiguity of the learning tasks emphasise the need to clarify the learning tasks at the beginning of the course. However, we don't want to present the material and the tasks too neatly packaged for the students. Instead, we want to preserve the complexity of the real working world, thereby fostering the contextual aspects of learning.

Future realisations of both versions of the course will also be built upon collaborative studying. Even if the online students didn't think that collaboration was as significant a support for learning as case based studying itself was, collaboration was experienced as a reason for 
positively toned emotions. Negatively toned emotions, on the other hand, resulted from the group members' different contributions to the learning task. Therefore, in the future realisations of the course, the online study groups will be required to negotiate right at the beginning of the course how they will deal with situations in which a group member doesn't contribute enough to the learning task. This means further enhancing the self directed aspects of learning. The challenge for the teacher is to support the group dynamics, especially by making sure the online study groups get started with their studying. In addition, the results indicated a need to increase tutoring in the students' online discussions (see Anderson et al., 2001).

Due to the small amount of research data concerning the students as producers of DVs, the results of this study are only suggestive. Therefore, our future research will continue to focus on how designing and producing DVs can support students' meaningful learning; in other words, what students learn and how the learning takes place. In addition, the research has encouraged the design of a Supporting Meaningful Learning through Producing and Using Digital Videos course in which Media Education students are responsible for the whole DV production process, thereby creating a complete product (see also Herrington et al., 2003). The research on this course focuses on how integrating the production of DVs with the problem based learning approach supports students' meaningful learning.

\section{Acknowledgments}

The European Social Fund (ESF) has provided financial support for analysing the research data and reporting the results as part of the LEVIKE - NetworkBased Higher Education: Case Lapland project.

\section{References}

Aho, S., Saarelainen, T. \& Suopajärvi, L. (2004). Creating the north by innovations. Six municipalities in the Finnish Tornio valley. In N. Aarsaether (Ed.), Innovations in the Nordic periphery (pp. 169-218). Nordregio R2004: 3. Stockholm: Nordregio.

Anderson, T., Rourke, L., Garrison, R. \& Archer, W. (2001). Assessing teaching presence in a computer conferencing context. JALN - Journal of Asynchronous Learning Networks, 5(2). [viewed 15 Mar 2006] http: / / www.sloanc.org/publications/jaln/v5n2/pdf/v5n2_anderson.pdf

Ausubel, D. P., Novak, J. D. \& Hanesian, H. (1978). Educational psychology: A cognitive view. New York: Holt, Rinehart and Winston.

Averill, J. R. (1982). Anger and aggression: An essay on emotion. New York: SpringerVerlag. 
Bandura, A. (1994). Self-efficacy. In V. S. Ramachaudran (Ed.), Encyclopedia of human behaviour (Vol. 4, pp. 71-81). New York: Academic Press. [viewed 15 Mar 2006] http: / / www.des.emory.edu/mfp/BanEncy.html

Barnes, L. B., Christensen, C. R. \& Hansen, A. J. (1994). Teaching with cases at the Harvard Business School. In L. B. Barnes, C. R. Christensen \& A. J. Hansen (Eds.), Teaching and the case method. Text, cases, and readings (3rd edition, pp. 3468). Boston, Massachusetts: Harvard Business School Press.

Bliss, T. \& Reynolds, A. (2004). Quality visions and focused imagination. In J. Brophy (Ed.), Using video in teacher education. Advances in research on teaching, Vol. 10 (pp. 29-51). Oxford: Elsevier Ltd.

Brockett, R. G. \& Hiemstra, R. (1991). Self-direction in adult learning: Perspectives on theory, research, and practice. London: Routledge.

Brophy, J. (Ed.) (2004). Using video in teacher education. Advances in research on teaching, Vol. 10. Oxford: Elsevier Ltd.

CTGV (Cognition and Technology Group at Vanderbilt) (1993). Designing learning environments that support thinking: The Jasper series as a case study. In T. M. Duffy, J. Lowyck \& D. H. Jonassen (Eds.), Designing environments for constructive learning (pp. 9-36). Berlin: Springer-Verlag.

Cohen, L. \& Manion, L. (1994). Research methods in education (4th ed.). London: Routledge.

Cohen, L., Manion, L. \& Morrison, K. (2003). Research methods in education (5th ed.). London: Routledge Falmer.

CDSL \& CLREP (Committee on Developments in the Science of Learning and Committee on Learning Research and Educational Practice) (Eds.) (2000). How people learn: Brain, mind, experience, and school. Washington, DC: National Academy Press. [verified 19 Feb 2007] http: / / www.nap.edu/books / 0309070368/html/

Engeström, Y. (1982). Mielekäs oppiminen ja opetus [Meaningful learning and teaching]. Helsinki, Finland: Valtion koulutuskeskus.

Enkenberg, J. (2001). Oppimisesta ja opetusmalleista yliopistokoulutuksessa [On learning and teaching models in university-level education] [Electronic version]. In J. Enkenberg, P.Väisänen, \& E. Savolainen (Eds.), Opettajatiedon kipinöitä. Kirjoituksia pedagogiikasta (pp. 7-33). Joensuun yliopisto, Savonlinnan opettajankoulutuslaitos, Finland.

Flynn, M. \& Soini, H. (2000). How education students conceptualize learning and learning disability: A European and North American sample [Electronic version]. In K. Kumpulainen (Ed.), In search of powerful learning environments for teacher education in the 21st century (pp. 80-90). Acta Universitatis Ouluensis B39.

Forger, G., Lyddon, P. \& Penfield, S. (2005). Internet literacy for diverse language learning environments. In P. Kommers \& G. Richards (Eds.), Proceedings of EDMEDIA 2005 Conference (CD-ROM) (pp. 466-474). June 27-July 2, Montreal, Canada. 
Hakkarainen, P. \& Saarelainen, T. (2005a). Producing digital video-supported cases with students - How to make it happen? In H. Ruokamo, P. Hyvönen, M. Lehtonen \& S.Tella (Eds.), Teaching-studying-learning (TSL) processes and mobile technologies - Multi-, inter-, and transdisciplinary (MIT) research approaches. Proceedings of the 12th International NBE (Former PEG) Conference (pp.183-191). September 14-17, Rovaniemi, Finland.

Hakkarainen, P. \& Saarelainen, T. (2005b). Towards meaningful learning through designing, producing and solving digital video-supported cases with students. In G. Richards (Ed.), Electronic versions (CD-ROM) of papers presented at E-Learn 2005 Conference (pp. 2081-2088). October 24-28, Vancouver, Canada.

Herrington, J. \& Oliver, R. (1995). Critical characteristics of situated learning: Implications for the instructional design of multimedia. In J. M. Pearce, A. Ellis, C. McNaught \& G. Hart (Eds.), Proceedings ASCILITE'95 Conference. University of Melbourne. http: / / www.ascilite.org.au/conferences/melbourne95/smtu/ papers/herrington.pdf

Herrington, J., Oliver, R. \& Reeves, T. C. (2003). Patterns of engagement in authentic online learning environments. Australian Journal of Educational Technology, 19(1), 59-71. http:/ / www.ascilite.org.au/ajet/ajet19/herrington.html

Hung, V. H. K., Keppell, M. \& Jong, M. S. Y. (2004). Learners as producers: Using project based learning to enhance meaningful learning through digital video production. In R. Atkinson, C. McBeath, D. Jonas-Dwyer \& R. Phillips (Eds), Beyond the comfort zone: Proceedings of the 21st ASCILITE Conference (pp. 428-436). December 5-8, Perth, Australia.

http: / / www.ascilite.org.au/ conferences/ perth04/procs/hung.html

Jonassen, D.H. (1995). Supporting communities of learners with technology: A vision for integrating technology with learning in schools. Educational Technology, 35(4), 60-63.

Jonassen, D. H. (2000). Computers as mindtools for schools. Engaging critical thinking. New Jersey: Prentice-Hall.

Jonassen, D. H. (2002). Learning as activity. Educational Technology, March-April, 4551.

Jonassen, D.H., Howland, J., Moore, J. \& Marra, M. (2003). Learning to solve problems with technology. A constructivist perspective (2nd ed.). Upper Saddle River, New Jersey: Merrill Prentice Hall.

Kansanen, P., Tirri, K., Meri, M., Krokfors, L. Husu, J. \& Jyrhämä, R. (2000). Teachers' pedagogical thinking. Theoretical landscapes, practical challenges. American University Studies. Series XIV Education, Vol. 47. New York: Peter Lang Publishing, Inc.

Karppinen, P. (2005). Meaningful learning with digital and online videos: Theoretical perspectives. AACE Journal (AACEJ), 13(3), 233-250. [viewed 4 Jan 2006, verified 19 Feb 2007] http:/ / www.editlib.org/index.cfm?fuseaction= Reader.ViewFullText\&paper_id=6021

Kearney, M. \& Schuck, S. (2004). Authentic learning through the use of digital video. In W. Au \& B. White (Eds.), Proceedings of the Australian Computers in Education Conference, July 2004, Adelaide, Australia. [viewed 4 Jan 2006, verified 
19 Feb 2007] http: / / www.ed-dev.uts.edu.au/teachered/research/dvproject / pdfs / ACEC2004.pdf

Kearney, M. \& Schuck, S. (2005). Students in the director's seat: Teaching and learning with student-generated video. In P. Kommers \& G. Richards (Eds.), Proceedings of ED-MEDIA 2005 (CD) (pp. 2864-2871). June 27-July 2, Montreal, Canada.

Kort, B. \& Reilly, R. (2002). Analytical models of emotions, learning, and relationships: Towards an affective-sensitive cognitive machine. Proceedings of the ITS 2002 - Intelligent Tutoring Systems Conference (pp. 955-962). June 2002, Biarritz, France. [viewed 1 Sep 2005, verified 19 Feb 2007] http: / / web.media.mit.edu/ reilly / its2002.pdf

Lehtinen, E. (1997). Tietoyhteiskunnan haasteet ja mahdollisuudet oppimiselle [Challenges and possibilities for learning in the information society]. In E. Lehtinen (Ed.), Verkkopedagogiikka (pp. 12-40). Helsinki: Edita.

Lewin, K. (1948). Resolving social conflicts. New York: Harper.

Liimatta, S. \& Karppinen, P. (2003). Dialogue and emotions in an online course module. Proceedings of the 11th International PEG Conference - Powerful ICT tools for learning and teaching (CD-ROM), June 28 - July 1, St. Petersburg, Russia.

McLellan, H. (2004). The case for case-based teaching in online classes. Educational Technology, 44(4, July-August), 14-18.

NCVER (National Centre for Vocational Education Research) (2003). Defining generic skills: At a glance. Adelaide: NCVER. [viewed 1 Feb 2006] http: / / www.ncver.edu.au/research/proj/nr2102b.pdf

Nevgi, A. \& Löfström, E. (2005). The quality of online learning - Teachers' and students' evaluations of meaningful learning experiences in online and blended courses. In S. Kiefer, J. Michalak, A. Sabanci \& K. Winter (Eds.), Analysis of educational policies in a comparative educational perspective (pp. 96-104). Linz, Austria: Pädagogische Hochschule des Bundes in Öberösterreich. [viewed 1 Dec 2006] http: / / www.phlinz.at/typo3/fileadmin/paedak_upload/technik / BIP_publication.pdf

Op't Eynde, P., De Corte, E. \& Verschaffel, L. (2001). “What to learn from what we feel ": The role of students' emotions in the mathematics classroom. In S. Volet \& S. Järvelä (Eds.), Motivation in learning contexts. Theoretical advances and methodological implications (pp. 149-167). Amsterdam: Pergamon.

Puolimatka, T. (2004). Tunteiden kognitiivisuus ja oppiminen [Cognitivity of emotions and learning]. Aikuiskasvatus 2/2004, 102-110.

Ruokamo, H. (2001). The Solver learning environment and anchored instruction on mathematical word problem-solving. In C. Montgomerie \& J. Viteli (Eds.), Proceedings of ED-MEDIA 2001 Conference (CD-ROM) (pp. 1595-1600). June 2530, Tampere, Finland.

Ruokamo, H. \& Pohjolainen, S. (2000). Distance learning in multimedia networks project: Main results. British Journal of Educational Technology, 31(2), 117-125.

Ruokamo, H., Tella, S., Vahtivuori, S., Tuovinen, H. \& Tissari, V. (2002). Pedagogical models in the design and assessment of network-based education. 
In P. Barker \& S. Rebelsky (Eds.), Proceedings of ED-MEDIA 2002 Conference (CD) (pp. 1676-1681). June 24-29, Denver, Colorado, USA.

Schedler, K., Summermatter, L. \& Schmidt, B. (2004). Managing the electronic government. From vision to practice. A volume in research in public management. Greenwich: Information Age Publishing Inc.

Schutz, P. A. \& DeCuir, J. T. (2002). Inquiry on emotions in education. Educational Psychologist, 37(2), 125-134.

Snellen, I. (2005). Technology and public administration: Conditions for successful e-government development. In G. Petroni \& F. Cloete (Eds.), New technologies in public administration (pp. 5-19). Amsterdam: IOS Press.

Soini, H. (1999). Education students' experiences of learning and their conceptions about learning disabilities. Towards a comprehensive theory of learning. Acta Universitatis Ouluensis E Scientiae Socialum 40. Oulu, Finland: Oulu University Press.

Tynjälä, P. (2001). Writing, learning and the development of expertise in higher education. In P. Tynjälä, L. Mason \& K. Lonka (Eds.), Writing as a learning tool. Integrating theory and practice (pp. 37-56). Dordrecht: Kluwer Academic Publishers.

Vahtivuori, S., Tella, S., Tissari, V., Tuovinen, H., Ruokamo, H. \& Vaattovaara, V. (2003). First evaluations of network-based education: Preliminary findings of the ICT programs evaluation project. In D. Lassner \& C. McNaught (Eds.), Proceedings of ED-MEDIA 2003 Conference (CD-ROM) (pp. 3177-3183). June 2328, Honolulu, USA.

Wiecha, J. M., Gramling, R., Joachim, P. \& Vanderschmidt, H. (2003). Collaborative e-learning using streaming video and asynchronous discussion boards to teach the cognitive foundation of medical interviewing: A case study. Journal of Medical Internet Research, 5 (2), 2003. [viewed 8 Mar 2006] http:/ / www.jmir.org/2003/2/e13/

Wosnitza, M. \& Nenniger, P. (2001). Perceived learning environments and the individual learning process: The mediating role of motivation in learning. In S. Volet \& S. Järvelä (Eds.), Motivation in learning contexts. Theoretical advances and methodological implications (pp. 171-187). Amsterdam: Pergamon.

Yrjönsuuri, Y. \& Yrjönsuuri, R. (2005). Intentionality and learning. Hamina, Finland: Oppilo.

Päivi Hakkarainen, University of Lapland, Faculty of Education, Centre for Media Pedagogy, Box 122, FIN-96101 Rovaniemi, Finland. Email: Paivi.Hakkarainen@ulapland.fi

Tarja Saarelainen, University of Lapland, Faculty of Social Sciences, Box 122, FIN-96101 Rovaniemi, Finland. Email: Tarja.Saarelainen@ulapland.fi

Heli Ruokamo, University of Lapland, Faculty of Education, Centre for Media Pedagogy, Box 122, FIN-96101 Rovaniemi, Finland.

Email: Heli.Ruokamo@ulapland.fi 